\title{
REFINEMENT OF NONINVASIVE METHODS FOR DIAGNOSING PRECANCER AND CANCER OF ORAL MUCOSA IN GENERAL DENTAL PRACTICE
}

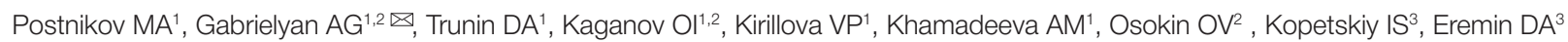

${ }^{1}$ Samara State Medical University, Samara, Russia

${ }_{2}^{2}$ Samara Regional Clinical Cancer Center, Samara, Russia

${ }^{3}$ Pirogov Russian National Research Medical University, Moscow, Russia

The search for and the application of available noninvasive methods for early diagnosis of oral mucosa (OM) neoplasia is a clinically significant problem. The aim of this study was to evaluate the effectiveness of the original score-based algorithm for assessing clinical data generated by a conventional and an autofluorescencebased examination in diagnosing OM cancer and assessing indications for a biopsy. We analyzed 134 medical histories and pathology reports of patients with oral neoplasia. The patients were assigned to 2 groups: the control group included 63 patients who underwent a standard visual and tactile examination with history taking and then were referred for an incisional biopsy followed by a histopathological examination of the specimens. In the main group consisting of 71 patients, a standard visual and tactile examination was complemented by an autofluorescence-based examination and the original score-based algorithm with the original index of required histopathological verification $(\mathrm{RHV})$ were used to assess indications for a biopsy. In both groups, the most commonly affected site was the tongue (72.4\%). The histopathological examination revealed that 28 patients from the main group and 14 patients from the control group had OM cancer $(p=0.051)$. Histologically, early-stage cancer was diagnosed in 17 patients from the main group and in 4 patients from the control group ( $p=0.004)$. The proposed algorithm allowed us to effectively (in 90\% of cases) diagnose precancer and cancer and avoid unnecessary biopsies.

Keywords: oral mucosa, precancer, cancer, required histological verification index (RHV)

Author contribution: Postnikov MA — literature analysis; Gabrielyan AG — study planning; Trunin DA, Kopetskiy IS, Eremin DA — analysis of the obtained data; Kaganov OI — manuscript draft; Kirillova VP — analysis of patients' records; Khamadeeva AM — interpretation of the obtained results; Osokin OV — data acquisition.

Compliance with ethical standards: the study was approved by the Ethics Committee of Samara State Medial University (Protocol № 27 dated February 12, 2018).

$\triangle$ Correspondence should be addressed: Alexey G. Gabrielyan

Michurina, 138, kv. 85, Samara, 443086; gabriel_002@mail.ru

Received: 18.12.2020 Accepted: 29.01.2021 Published online: 18.02.2021

DOI: $10.24075 /$ brsmu.2021.005

\section{СОВЕРШЕНСТВОВАНИЕ НЕИНВАЗИВНЫХ МЕТОДОВ ДИАГНОСТИКИ ПРЕДРАКОВЫХ И ЗЛОКАЧЕСТВЕННЫХ ЗАБОЛЕВАНИЙ СЛИЗИСТОЙ ОБОЛОЧКИ РТА НА ПРИЕМЕ У СТОМАТОЛОГА}

М. А. Постников ${ }^{1}$, А. Г. Габриелян ${ }^{1,2} 凶$, Д. А. Трунин ${ }^{1}$, О. И. Каганов ${ }^{1,2}$, В. П. Кириллова ${ }^{1}$, А. М. Хамадеева', О. В. Осокин², И. С. Копецкий Д. А. Еремин

${ }^{1}$ Самарский государственный медицинский университет, Самара, Россия

${ }^{2}$ Самарский областной клинический онкологический диспансер, Самара, Россия

${ }^{3}$ Российский научно-исследовательский медицинский университет имени Н. И. Пирогова, Москва, Россия

Поиск и применение доступных неинвазивных методов ранней диагностики новообразований слизистой оболочки рта (СОР) является актуальной задачей. Целью работы было выявить эффективность использования разработанного алгоритма балльной оценки данных клинического обследования в сочетании с проведением аутофлуросцентной стоматоскопии (АФС) для постановки диагноза злокачественных новообразований СОР и принятия решения о необходимости проведения биопсии. Проведен анализ 134 амбулаторных карт больных, которым выполняли биопсию. Пациенты были разделены на две группы: в контрольную группу вошли 63 человека, которым после проведенного традиционного обследования (опроса, осмотра, пальпации) проводили инцизионную биопсию с последующим морфологическим исследованием; у 71 пациента основной группы применяли (ИНГВ). Установлено, что патологические состояния СОР локализовались в большей степени на языке у 72,4\% пациентов в обеих группах. После выполненных биопсий в основной группе злокачественные опухоли СОР были диагностированы у 28 пациентов, в контрольной - у 14 ( $p=0,051)$. В основной группе начальные стадии рака СОР установлены у 17 человек после биопсии, в контрольной - у 4 ( $p=0,004)$. Использование разработанного алгоритма позволило с высоким процентом точности (90\%) диагностировать предраковые и злокачественные новообразования и проводить инвазивные методы исследования (биопсию) строго по показаниям.

Ключевые слова: слизистая оболочка рта, СОР, предрак, злокачественное образование, индекс необходимости гистологической верификации, ИНГВ

Вклад авторов: М. А. Постников - анализ литературы; А. Г. Габриелян - планирование исследования; Д. А. Трунин, И. С. Копецкий, Д. А. Еремин анализ данных; О. И. Каганов - подготовка черновика рукописи; В. П. Кириллова - обработка и анализ первичной документации; А. М. Хамадеева интерпретация данных; О. В. Осокин - сбор данных.

Соблюдение этических стандартов: исследование одобрено этическим комитетом Самарского государственного медицинского университета (протокол № 27 от 12 февраля 2018 г.).

$\bigotimes$ Для корреспонденции: Алексей Григорьевич Габриелян

ул. Мичурина, д. 138, кв. 85, г. Самара, 443086; gabriel_002@mail.ru

Статья получена: 18.12.2020 Статья принята к печати: 29.01.2021 Опубликована онлайн: 18.02.2021

DOI: $10.24075 /$ vrgmu.2021.005 
According to statistics, over 300,000 new cases of oral cancer are reported worldwide annually [1]. In Russia, over 9,000 patients were diagnosed with oral mucosal (OM) malignancies in 2018; of them, 199 were residents of Samara region. OM cancer is the $18^{\text {th }}$ most common cancer; this malignancy is histologically confirmed in $97 \%$ of suspected cases [2]. Although OM cancer develops on external body surfaces, 62\% of Russian patients and $63 \%$ of patients residing in Samara region present with advanced stages. Delays in diagnosis are associated with a number of factors, including low suspicion by dentists, the lack of awareness among patients, and the absence of screening programs. General dentists working in secondary prevention do not have a clear diagnostic algorithm for oral cancer screening and often misdiagnose their patients [3-5]. A physical examination remains the main screening (but not diagnostic) test for oral cancer [6-8]. Most patients with suspicious lesions are referred for a biopsy. This may result in overdiagnosis [9-11]. A biopsy is an invasive method of tissue sampling. Biopsied specimens of oral mucosa are subjected to a histopathological examination performed to establish a differential and a final diagnosis. An oral tissue biopsy poses a risk of adverse events, so a patient should be referred for this procedure only when he/she has clear indications for it, including a suspicious lesion. A pathology report plays a critical role in establishing a definitive diagnosis, choosing an adequate treatment and predicting a patient's outcome. This is why an OM biopsy should be performed only when clearly indicated and required for a differential diagnosis. Autofluorescencebased visualization of the oral cavity is a well-known method of oral cancer detection [12-14]. There has been a wealth of studies investigating this diagnostic method, but none of them looked at the integrated approach combining a conventional clinical examination and autofluorescence-based visualization [15-18]. In 2020, we patented a simple noninvasive method for assessing indications for biopsy in patients with a suspected vermillion lip border neoplasm that can be used in general dental practice [19].

The aim of this study was to evaluate the effectiveness of the original score-based algorithm in diagnosing $\mathrm{OM}$ precancer and cancer and assessing indications for biopsy during a standard clinical examination complemented by autofluorescence-based visualization of the oral cavity.

\section{METHODS}

We analyzed 134 medical histories and pathology reports of patients with oral neoplasia who had been referred to Samara

Table 1. Lesions sites in the main and control groups
Regional Clinical Cancer Center by the general dentists of Samara clinics between 2014 and 2019.

The patients were divided into 2 groups according to the method of clinical examination. The control group (M2) comprised 63 patients with suspicious oral mucosal lesions (preliminary diagnosis: oral neoplasia) who had been referred to the Cancer Center by their dentists between 2014 and 2019. At the Center, the patients underwent a standard visual and tactile examination, and their medical histories were taken; then, the patients underwent an incisional biopsy. The collected specimens were studied by a pathologist at the Center's laboratory. In the main group (M1) consisting of 71 patients, a standard visual and tactile examination was complemented by an autofluorescence-based examination and the original score-based algorithm with the original index of required histopathological verification (RHV) were used to assess indications for a biopsy. This algorithm allows discriminating between inflammation or precancer and cancer (Fig. 1). In both groups, incisional biopsies were performed under local anesthesia using conchotomes; the obtained specimens were subjected to a histopathological examination (Fig. 2). In the main group incisional biopsy was performed on those patients whose RHV index was above 5.

The following inclusion criteria were applied: any age or sex; superficial oral cavity neoplasia; first-time referral to an oncologist by a general dentist. Patients who had been referred to an oncologist by other specialists, self-referred patients, those who had submucosal malignancies and those who refused to participate were excluded from the study.

The patients were comparable in terms of $\operatorname{sex}(\mathrm{M}: \mathrm{F}=3: 1$; $p=0.858)$, age (63 \pm 2.8 years in the control group, $71 \pm 2.8$ years in the main group) and lesion site (Table 1). The original protocol for cancer detection applied in the main group consisted in taking a medical history, conducting a visual and tactile examination of the oral cavity, and a visual autofluorescencebased examination with an AFS400 handpiece (Polironik; Russia). Results produced by each component of the protocol are expressed as points and are then summated and expressed in the form of the RHV index. The index value specified in the oral cavity assessment form must contain a letter indicating the site of the detected lesion. The RHV index must be calculated for each detected lesion. There must be a separate assessment form for each detected lesion. If the $\mathrm{RHV}$ index value is below 5, a patient should receive treatment and be invited for a follow-up examination. If the RHV index value is 5 or above, a biopsy is recommended. The pathology report concluding precancer or cancer is the main criterion

\begin{tabular}{|c|c|c|c|c|}
\hline \multirow{3}{*}{ Site } & \multicolumn{4}{|c|}{ Groups } \\
\hline & \multicolumn{2}{|c|}{$\begin{array}{c}\text { Control M2 } \\
n=63\end{array}$} & \multicolumn{2}{|c|}{$\begin{array}{c}\text { Main M1 } \\
n=71\end{array}$} \\
\hline & $n$ & $\%$ & $n$ & $\%$ \\
\hline Tongue & 29 & 46 & 33 & 47 \\
\hline Upper alveolus & 1 & 2 & - & 0 \\
\hline Lower alveolus & 3 & 5 & 1 & 1 \\
\hline Mouth floor & 14 & 22 & 17 & 24 \\
\hline Hard palate & 2 & 3 & 3 & 4 \\
\hline Soft palate & 1 & 2 & 2 & 3 \\
\hline Cheek & 13 & 20 & 15 & 21 \\
\hline Total & 63 & 100 & 71 & 100 \\
\hline
\end{tabular}

Note: Pearson's coefficient $=2.7567 ; p=0.8386$ 


\begin{tabular}{|c|c|c|}
\hline $\begin{array}{c}\text { Date: } \\
\text { First visit/followup visit } \\
\text { (underline as appropriate) }\end{array}$ & \multirow{3}{*}{ POINTS } & \multirow{2}{*}{$\begin{array}{l}\text { Protocol for visual, tactile and autofluorescence-based examination of } \\
\text { vermillion lip border and oral mucosa }\end{array}$} \\
\hline Patient's full name & & \\
\hline Date of birth & & \multirow{5}{*}{$\begin{array}{l}\text { a) lip, vermillion border / labial mucosa, corner upper / lower / right / left } \\
\text { b) mouth vestibule upper / lower / right / left } \\
\text { c) vestibular alveolar mucosa upper / lower jaw, right / left / front } \\
\text { d) buccal mucosa right / left } \\
\text { e) labial alveolar mucosa upper / lower jaw, right / left / front } \\
\text { f) retromolar space right / left } \\
\text { g) floor mouth mucosa frontal / lateral / right / left } \\
\text { h) ventral surface of tongue right / left } \\
\text { i) lateral border of tongue right / left } \\
\text { j) tip of tongue } \\
\text { k) dorsal surface of tongue right / left } \\
\text { l) base of tongue right / left } \\
\text { m) hard palate mucosa right / left n) soft palate mucosa right / left } \\
\text { o) anterior faucial pillars right / left }\end{array}$} \\
\hline $\begin{array}{l}\text { History (underline as appropriate) } \\
\text { Any symptoms }-0.25 \text { points, no symptoms }-0 \text { points } \\
\text { Onset of symptoms }-14 \text { days ago or earlier }-0.25 \\
\text { points } \\
\text { Less than } 14 \text { days ago }-0 \text { points } \\
\text { Any unhealthy lifestyle habits (except smoking) }-0.25 \\
\text { points } \\
\text { Smoking }-0.5 \text { points } \\
\text { No unhealthy lifestyle habits }-0 \text { points } \\
\text { Occasional exposure to occupational } \\
\text { hazards }-0.25 \text { points } \\
\text { No exposure to occupational hazards }-0 \text { points }\end{array}$ & 0,25 & \\
\hline $\begin{array}{l}\text { Visual examination (underline as appropriate) } \\
\text { Erosions, excoriation, aphthae, ulceration, chapping or } \\
\text { cracking, scarring, hyperkeratosis }-2 \text { points } \\
\text { Discoloration, nodules, bumps, vesicles, abscesses, } \\
\text { cysts }-1 \text { point } \\
\text { No lesions }-0 \text { points } \\
\text { Does not require dental care }-0 \text { points } \\
\text { Requires dental care }-0.25 \text { points }\end{array}$ & 0,25 & \\
\hline $\begin{array}{l}\text { Tactile examination (underline as appropriate) } \\
\text { No palpable growth }-0 \text { points } \\
\text { Palpable growth }-1 \text { point } \\
\text { Palpable regional lymph nodes }-0.5 \text { points } \\
\text { Regional lymph nodes not palpable }-0 \text { points }\end{array}$ & 0 & \\
\hline $\begin{array}{l}\text { Autofluorescence-based examination } \\
\text { (underline as appropriate) } \\
\text { Dark-brown fluorescence }-2 \text { points } \\
\text { Pinkish red fluorescence }-1 \text { point } \\
\text { Green fluorescence }-0 \text { points }\end{array}$ & 2 & \\
\hline RHV index & ИНГВ $=5,75 j$ & \\
\hline
\end{tabular}

Fig. 1. An algorithm for assessing indications for biopsy in patients with vermillion lip border and oral mucosa neoplasia presenting to a dentist for a clinical examination indicating the efficacy of the proposed algorithm. Fig. 1-4 show a visual examination of the patient with a tongue neoplasm conducted under natural light and with an AFS handpiece. The following variables were compared between the main and control groups: presenting complaints, pathologies detected on examination, the proportion of precancerous conditions and malignancies, histologically identified stages of cancer. Multivariate logistic regression models were applied to analyze the data of patients with $\mathrm{OM}$ malignancies. Differences were considered significant at $p<0.05$ Statistical analysis was carried out in Statistica 10.0 (Dell; USA).

\section{RESULTS}

The groups differed in terms of frequency of complaints. In the main group, complaints of a suspicious growth were more frequent than in the control group (0.54 vs. 1.17 times, respectively). Pain was reported by $23.9 \%$ of patients from $\mathrm{M} 1$ and by $47.6 \%$ of patients from M2. In both groups, discomfort was very pronounced; a burning sensation and itching were

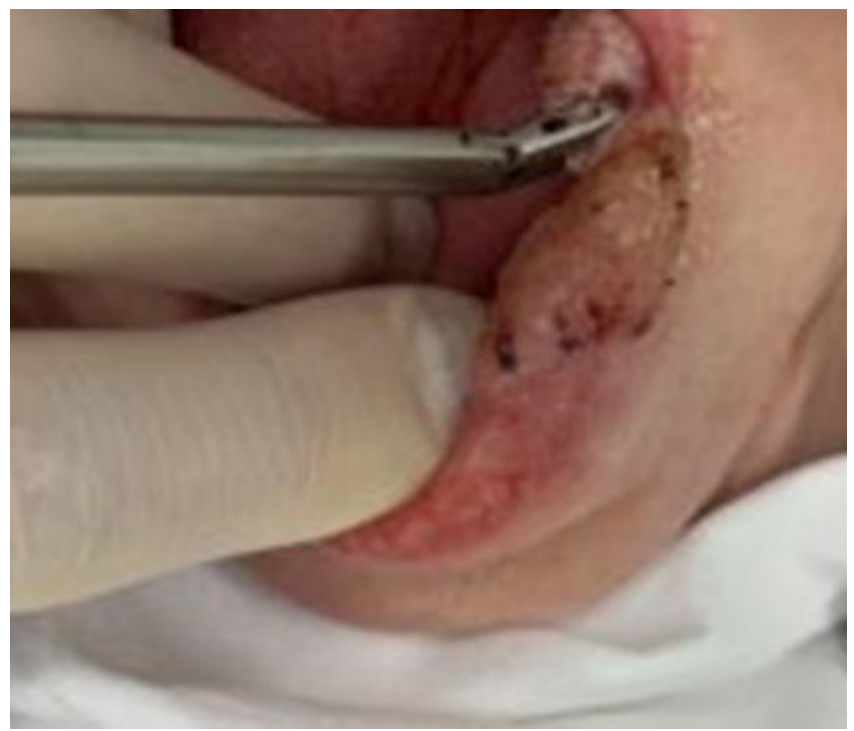

Fig. 2. Biopsy of a buccal mucosa lesion 
Table 2. Presenting complaints in the main (M1) and control (M2) groups

\begin{tabular}{|c|c|c|c|c|c|c|c|}
\hline \multirow{2}{*}{ Groups } & Complaints & Suspicious growth & Pain & Discomfort & $\begin{array}{c}\text { Burning } \\
\text { sensation }\end{array}$ & Itching & Bleeding \\
\hline \multirow{3}{*}{ M1 } & Detected & $35.2 \%$ & $23.9 \%$ & $64.8 \%$ & $40.8 \%$ & $29.6 \%$ & $7.04 \%$ \\
\cline { 2 - 8 } & Not detected & $64.8 \%$ & $76.1 \%$ & $35.2 \%$ & $59.2 \%$ & $70.4 \%$ & $92.96 \%$ \\
\cline { 2 - 8 } & Difference & 0.54 times & 3.17 times & 1.84 times & 1.45 times & 0.98 times & 13.2 times \\
\hline \multirow{3}{*}{ M2 } & Detected & $53.9 \%$ & $47.6 \%$ & $47.6 \%$ & $42.9 \%$ & $39.7 \%$ & $22.2 \%$ \\
\cline { 2 - 8 } & Not detected & $46.1 \%$ & $52.4 \%$ & $19.1 \%$ & $57.1 \%$ & $60.3 \%$ & $77.8 \%$ \\
\cline { 2 - 8 } & Difference & 1.17 times & 1.1 times & 4.25 times & 1.33 times & 1.52 times & 3.5 times \\
\hline
\end{tabular}

reported at the same frequency (Fig. 5). Table 3 compares the clinical manifestations of the pathology between groups $M 1$ and M2. Mucosal discoloration was observed 0.82 times more often in the main group than in the control group (54.9\% vs. $28.4 \%$ ). A coated tongue was present in $62.0 \%$ and $60.3 \%$ of patients from the main and control groups, respectively. Hyperkeratosis was detected in $45.1 \%$ and $58.7 \%$ of patients, respectively. Erosions prevailed in the control group (55.6\% vs. $36.6 \%)$. Hyperplasia and atrophy were detected in $11.1 \%$ to $31.0 \%$ of cases.

The histopathological examination confirmed precancer in 18 and 36 patients from the main and control groups, respectively $(p=0.016)$. Oral cancer was confirmed in 28 patients from the control group and only 14 patients from the main groups $(p=0.051)$. According to the pathology reports, 7 patients in the main group and 31 patients in the control group had inflammation ( $p=0.001$ ) (Fig. 6). Early-stage cancer was detected in 17 patients from the main group and 4 patients from the control group $(p=0.004)$. There were no significant differences in the frequency of late-stage cancer between the groups: advanced cancer was detected

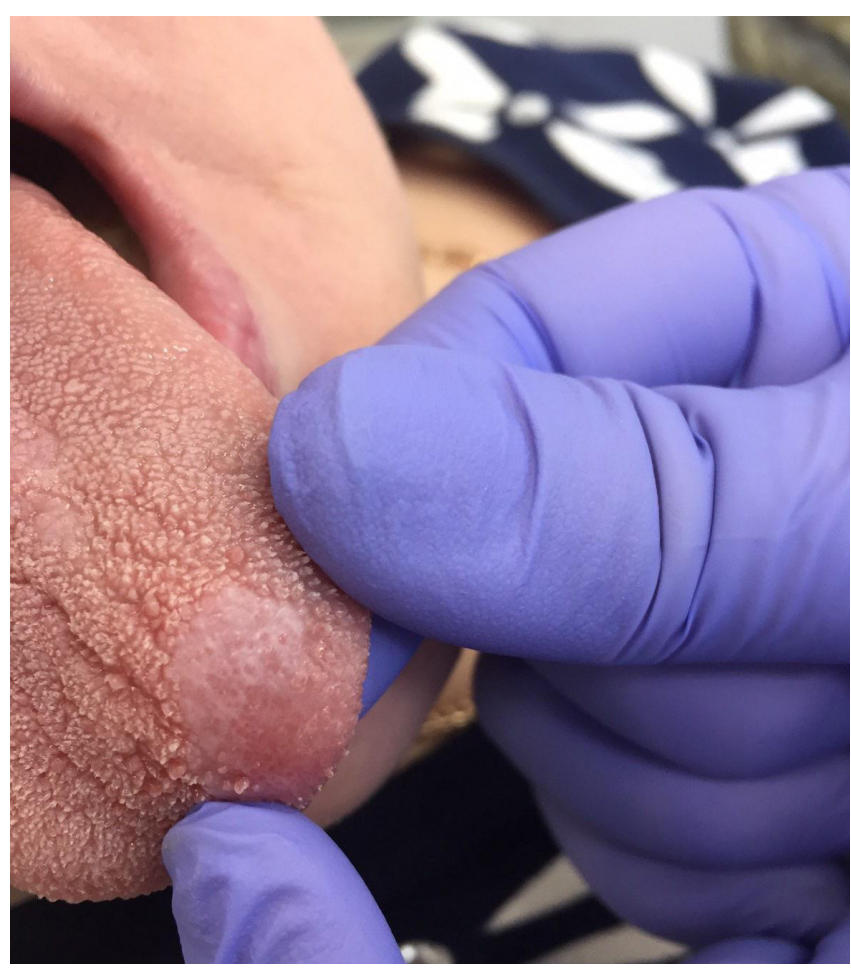

Fig. 3. Lingual mucosa lesion detected on clinical examination in 11 and 10 patients from the main and control groups, respectively (Fig. 7).

\section{DISCUSSION}

Pain, discomfort and a burning sensation were more pronounced in the control group than in the main group; erosions were also more common for the control group. By contrast, a coated tongue and dysplasia were more prevalent in the main group. The tongue was the most commonly affected site in both groups $(46 \%$ and $47 \%$ in the control and main groups, respectively), which is consistent with the literature $[2,5]$. Patients with $\mathrm{OM}$ inflammation pose the main diagnostic challenge for primary care dentists. They are often referred for invasive diagnostic procedures for no justified reason. The proposed score-based assessment of biopsy indications in patients with suspicious growths on the vermillion border or oral cavity mucosa during a conventional clinical examination complemented by autofluorescencebased visualization allowed us to confirm precancerous conditions and cancer in $90 \%$ of patients in the main group

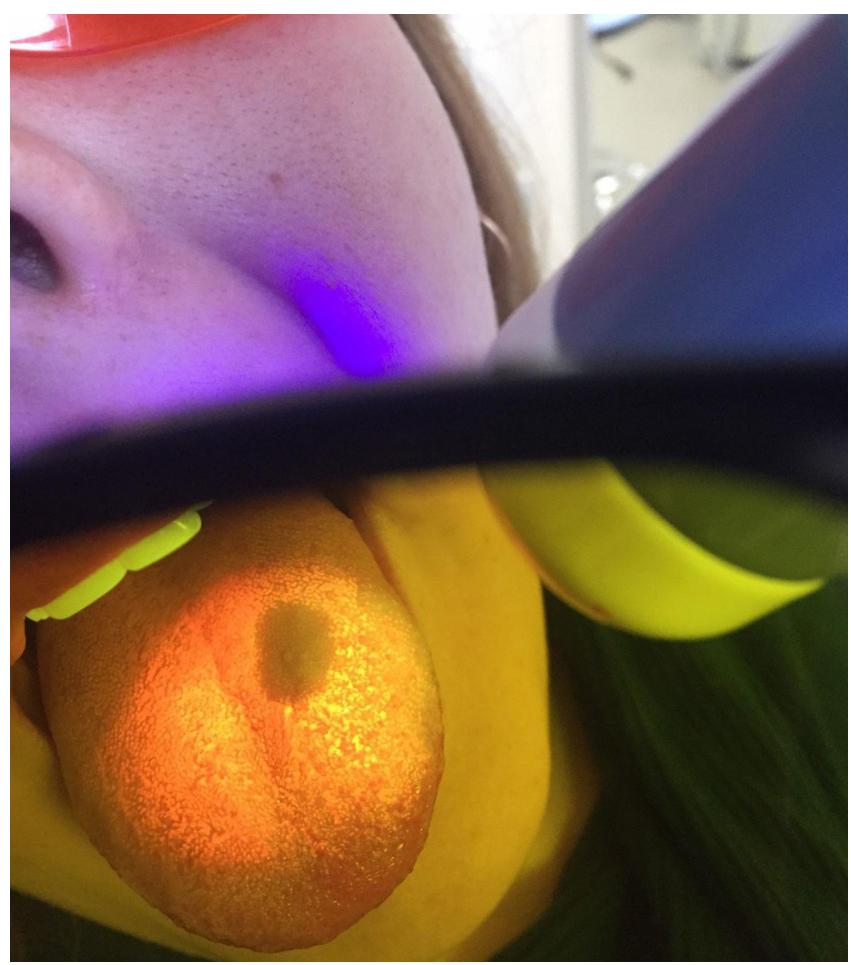

Fig. 4. Brown autofluorescence of lingual mucosa under AFS400 light 


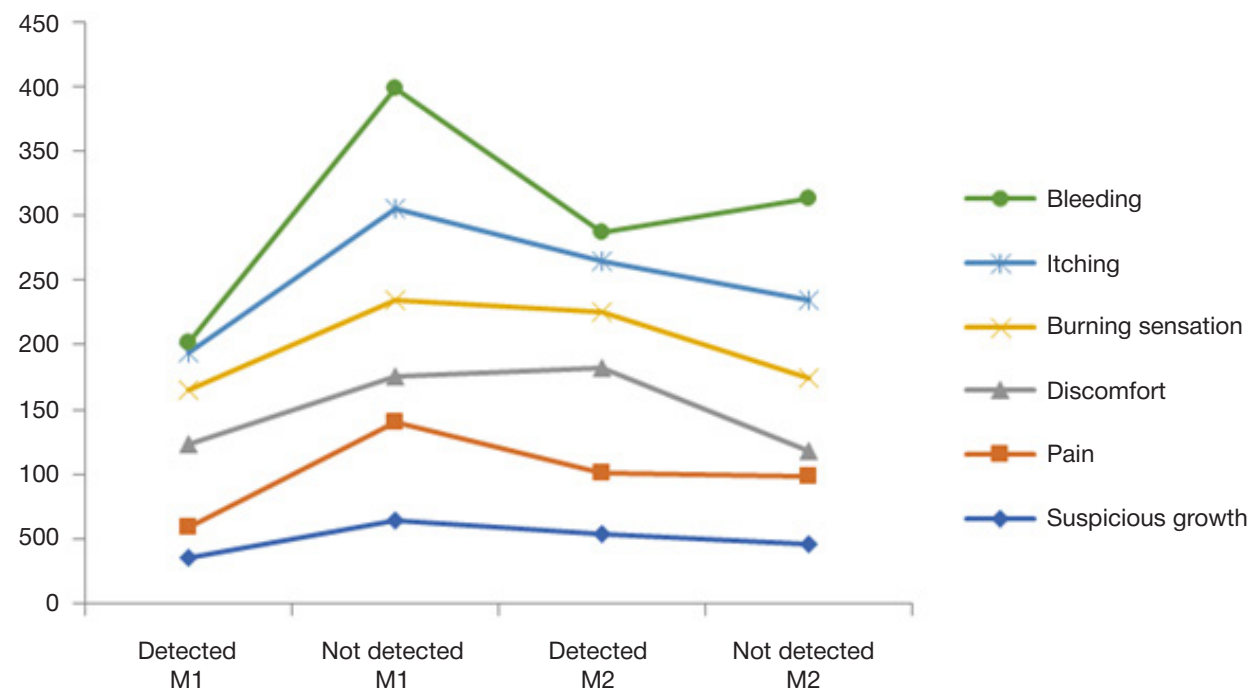

Fig. 5. Distribution of presenting complaints in the main (M1) and control (M2) groups on clinical examination

Table 3. Clinical manifestations detected on examination in the main (M1) and control (M2) groups (under natural light)

\begin{tabular}{|c|c|c|c|c|c|c|c|c|c|c|}
\hline & \multirow{3}{*}{$\begin{array}{l}\text { ral mucosa } \\
\text { xamination }\end{array}$} & \multirow{3}{*}{$\begin{array}{c}\text { Mucosal } \\
\text { discoloration }\end{array}$} & \multirow{3}{*}{$\begin{array}{l}\text { Moist, } \\
\text { glossy } \\
\text { mucosa }\end{array}$} & \multirow{2}{*}{\multicolumn{3}{|c|}{ Coated tongue }} & \multicolumn{4}{|c|}{ Signs of pathology } \\
\hline & & & & & & & \multirow{2}{*}{ Hyperkeratosis } & \multirow{2}{*}{ Hyperplasia } & \multirow{2}{*}{ Atrophy } & \multirow{2}{*}{$\begin{array}{l}\text { Erosion/ } \\
\text { ulceration }\end{array}$} \\
\hline & & & & Present & Removable & Non-removable & & & & \\
\hline \multirow{3}{*}{ M1 } & Detected & $54.9 \%$ & $43.7 \%$ & $62.0 \%$ & $31.0 \%$ & $28.2 \%$ & $45.1 \%$ & $31.0 \%$ & $12.7 \%$ & $36.6 \%$ \\
\hline & Not detected & $45.1 \%$ & $56.3 \%$ & $38.0 \%$ & $69.0 \%$ & $71.8 \%$ & $54.9 \%$ & $69.0 \%$ & $87.3 \%$ & $63.4 \%$ \\
\hline & Difference & 0.82 times & 1.29 times & 1.63 times & 2.23 times & 2.55 times & 1.22 times & 2.23 times & 6.9 times & 1.73 times \\
\hline \multirow{3}{*}{ M2 } & Detected & $28.4 \%$ & $53.9 \%$ & $60.3 \%$ & $33.8 \%$ & $36.5 \%$ & $58.7 \%$ & $17.5 \%$ & $11.1 \%$ & $55.6 \%$ \\
\hline & Not detected & $71.4 \%$ & $46.1 \%$ & $39.7 \%$ & $66.2 \%$ & $63.5 \%$ & $41.3 \%$ & $82.5 \%$ & $88.9 \%$ & $44.4 \%$ \\
\hline & Difference & 2.5 times & 1.17 times & 1.52 times & 3.2 times & 1.7 times & 1.42 times & 4.7 times & 8.0 times & 1.25 times \\
\hline
\end{tabular}

Main group $n=71 \quad$ Control group $n=63$

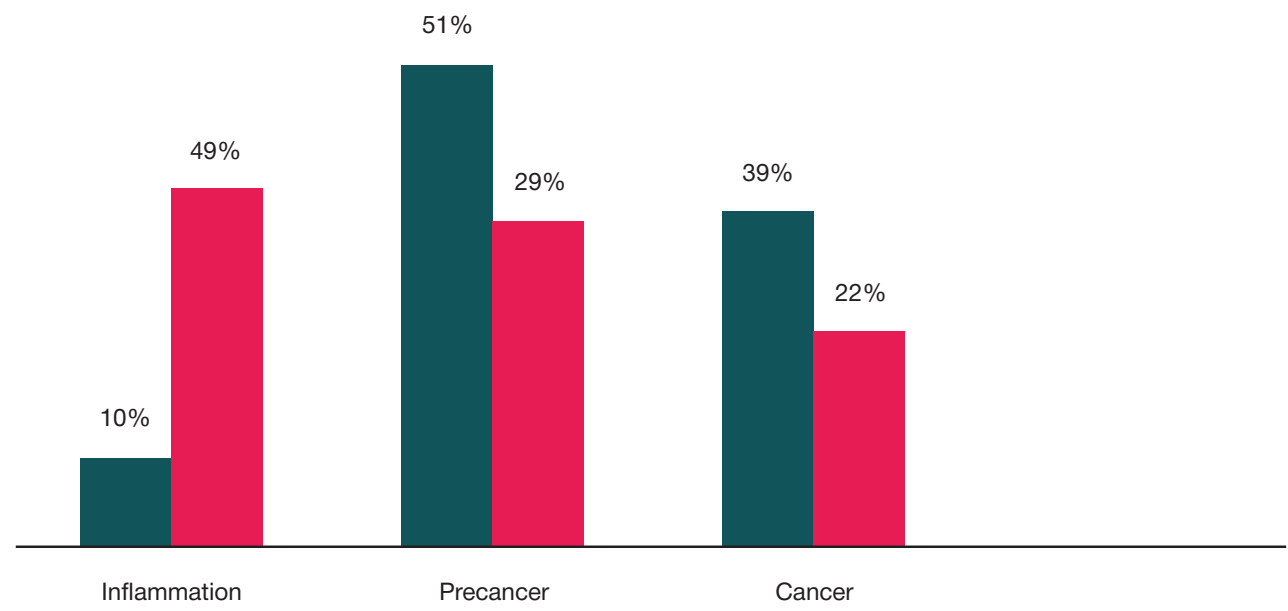

Fig. 6. Distribution of patients in the groups by histologically verified diagnoses and $51 \%$ of patients in the control group $(p=0.001)$. The proposed method has advantages over the conventional examination in terms of early cancer detection and secondary prevention because it can be used by general dentists. According to the literature, a physical examination cannot

be used as a diagnostic test for establishing a differential diagnosis and should be complemented by fluorescencebased and other methods. Our study demonstrates the effectiveness of such methods used as an adjunct to traditional procedures [12, 14-16]. 


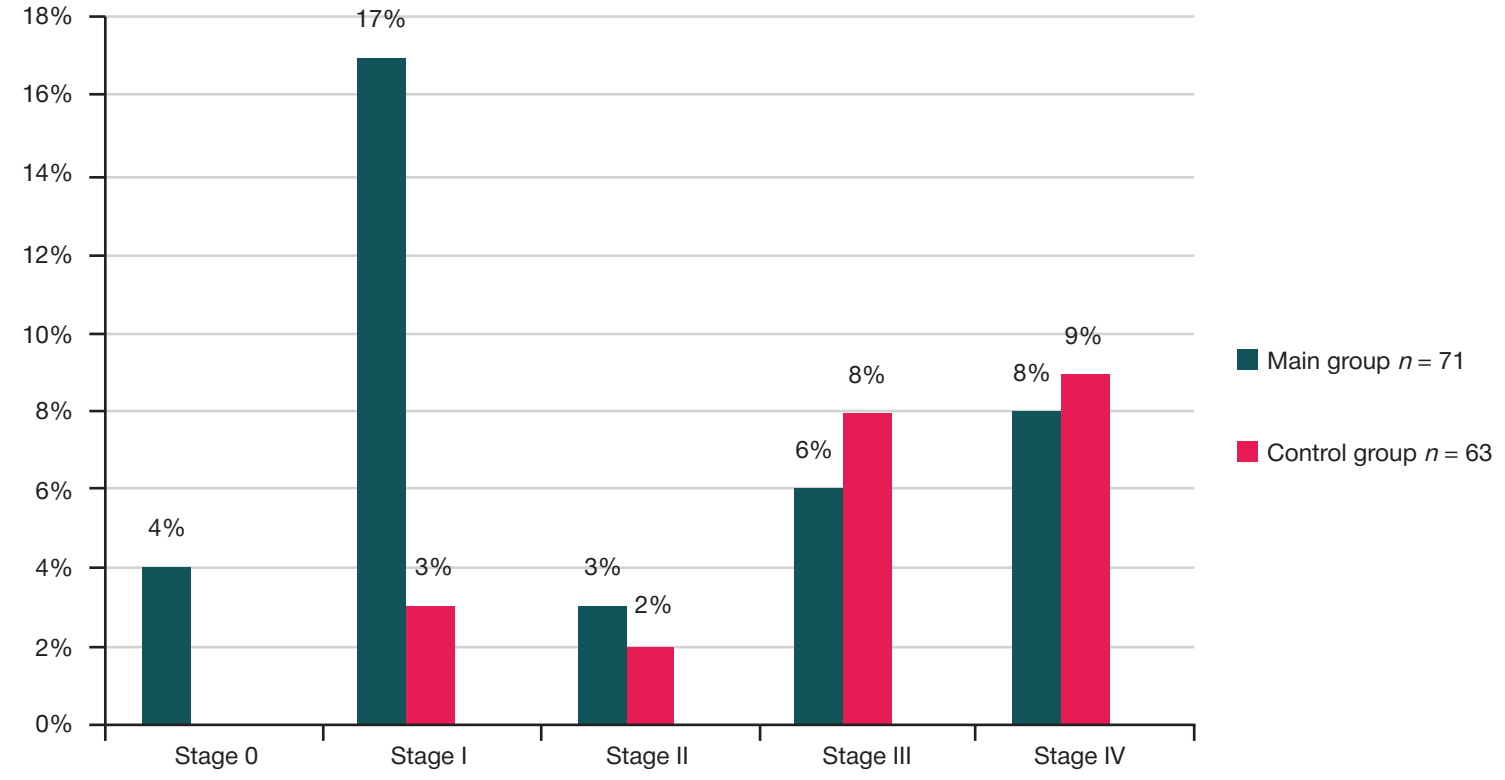

Fig. 7. Distribution of patients in the groups by cancer stages CONCLUSION

Our score-based assessment of data yielded by a conventional clinical examination complemented by an autofluorescence- based examination allowed us to effectively (in 90\% of cases) diagnose precancer and cancer, better detect early-stage OM cancer in comparison with traditional examinations $(24 \%$ and $5 \%$ respectively) and avoid unnecessary biopsies.

\section{References}

1. Global Cancer Statistics 2018: GLOBOCAN Estimates of Incidence and Mortality Worldwide for 36 Cancers in 185 Countries.

2. Kaprin AD, Starinskii VV, Shakhzadovoi AO. Sostojanie onkologicheskoj pomoshhi naseleniju Rossii $\vee 2019$ godu. M. MNIOI im. P. A. Gercena - filial FGBU «NMIC radiologii» Minzdrava Rossii, 2020; s. 239. Russian.

3. Starikov VI. Opuholi golovy i shei: uchebnoe posobie dlja studentov IV kursa stomatologicheskogo fakul'teta. Har'kov: 2014; s. 73. Russian.

4. Domanin AA, Solnyshkina AF. Diagnostika predraka slizistoj obolochki polosti rta. Privolzhskij onkologicheskij vestnik. 2011; 1: 45-46. Russian.

5. Kostina IN. Struktura, lokalizacija opuholevyh i opuholepodobnyh zabolevanij polosti rta. Problemy stomatologii. 2014; 4: 33-39. Russian.

6. Nikolenko V. N. i dr. Sovremennyj vzgljad na diagnostiku i lechenie raka slizistoj obolochki polosti rta. Golova i sheja. 2018; 4: 36-42. Russian.

7. Stepanov DA, Fedorova MG, Averkin NS. Morfologicheskie issledovanija v stomatologii. Vestnik Penzenskogo gosudarstvennogo universiteta. 2019; 1 (25): 80-85. Russian.

8. Filimonova LB, Mezhevikina GS, Marshuba LO. Ispol'zovanie autofluorescentnoj stomatoskopii kak skriningovogo metoda diagnostiki predrakovyh sostojanij i onkologicheskih zabolevanij slizistoj obolochki rta na stomatologicheskom prieme. Nauka molodyh. 2020; 8 (1): 80-85. Russian.

9. Mezhevikina GS, Gluhova EA. Sovremennye metody diagnostiki predrakovyh i rakovyh izmenenij slizistoj obolochki rta. Nauka molodyh. 2018; 6 (4): 600-6. Russian.

10. Ephros H. Oral Tissue Biopsy. Medscape. 2018: 1-13.

11. LeontevaES, Egorov MA, KuznecovaRG. Immunogistohimicheskie markery $v$ diagnostike predrakovyh porazhenij slizistoj obolochki polosti rta i krasnoj kajmy gub. Prakticheskaja medicina. 2012; 1 : 20-22. Russian.
12. Maksimovskaya LN, Erk AA, Bulgakova NN, Zubov BV. Primenenie autofluorescentnoj stomatoskopii dlja onkoskrininga zabolevanij slizistoj obolochki polosti rta. Stomatologija dlja vseh. 2016; 4 (77): 34-37. 13. Pursanova AE, Kazarina LN, Gushhina OO, Serhel EV, Belozerov AE, Abaev ZM. Kliniko-immunologicheskie osobennosti predrakovyh zabolevanij slizistoj obolochki rta i krasnoj kajmy gub. Stomatologija. 2018; 5: 23-26.

14. Pozdnyakova TI, Smirnova YuA, Volkov EA, Bulgakova NN. Vozmozhnosti autofluorescentnoj spektroskopii $\vee$ vyjavlenii predrakovyh zabolevanij slizistoj obolochki polosti rta. DentalRevju. 2013; 2: 46-47.

15. Amirchaghmaghi M, Mohtasham N, Delavarian Z, Shakeri MT, Hatami M, Mozafari PM. The diagnostic value of the native fluorescence visualization device for early detection of premalignant/malignant lesions of the oral cavity. Photodiagnosis Photodyn Ther. 2018; 21: 19-27.

16. Simonato LE, Tomo S, Navarro RS, Villaverde AGJB. Fluorescence visualization improves the detection of oral, potentially malignant, disorders in population screening. Photodiagnosis Photodyn Ther. 2019; 27: 74-8.

17. Meleti M, Giovannacci I, Vescovi P, Pedrazzi G, Govoni P, Magnoni C. Histopathological determinants of autofluorescence patterns in oral carcinoma. Oral Dis. 2020.

18. Shuhorova YuA, Tkach TM, Burakshaev SA, Postnikov MA. Onkonastorozhennost $v$ praktike vracha-stomatologa na ambulatornom prieme. Institut stomatologii. 2020; 3 (88): 20-22.

19. Orlov AE, Kaganov OI, Postnikov MA, Vozdvizhensky MO, Trunin DA, Makhonin AA, Gabrielyan AG, Tkachev MV, Kirilova VP, Osokin OV, Kerosirov AP, Akhmadieva EO, Baranov RA, Shurygina OV, avtory. Sposob opredelenija pokazanij dlja vypolnenija gistologicheskoj verifikacii obrazovanija krasnoj kajmy gub i slizistoj polosti rta u bol'nogo na prieme u vracha stomatologa. Patent RF \# 2019133760. 22.10.2019. 


\section{Литература}

1. Global Cancer Statistics 2018: GLOBOCAN Estimates of Incidence and Mortality Worldwide for 36 Cancers in 185 Countries.

2. Каприн А. Д., Старинский В. В., Шахзадовой А. О. Состояние онкологической помощи населению России в 2019 году. М.: МНИОИ им. П. А. Герцена - филиал ФГБУ «НМИЦ радиологии» Минздрава России, 2020; с. 239.

3. Стариков В. И. Опухоли головы и шеи: учебное пособие для студентов IV курса стоматологического факультета. Харьков: 2014; с. 73.

4. Доманин А. А., Солнышкина А. Ф. Диагностика предрака слизистой оболочки полости рта. Приволжский онкологический вестник. 2011; 1: 45-46.

5. Костина И. Н. Структура, локализация опухолевых и опухолеподобных заболеваний полости рта. Проблемы стоматологии. 2014; 4: 33-39.

6. Николенко В. Н. и др. Современный взгляд на диагностику и лечение рака слизистой оболочки полости рта. Голова и шея. 2018; 4: 36-42.

7. Степанов Д. А., Федорова М. Г., Аверкин Н. С Морфологические исследования в стоматологии. Вестник Пензенского государственного университета. 2019; 1 (25): 80-85.

8. Филимонова Л. Б., Межевикина Г. С, Маршуба Л. О. Использование аутофлуоресцентной стоматоскопии как скринингового метода диагностики предраковых состояний и онкологических заболеваний слизистой оболочки рта на стоматологическом приеме. Наука молодых. 2020; 8 (1): 80-85.

9. Межевикина Г. С., Глухова Е. А. Современные методы диагностики предраковых и раковых изменений слизистой оболочки рта. Наука молодых. 2018; 6 (4): 600-6.

10. Ephros H. Oral Tissue Biopsy. Medscape. 2018: 1-13.

11. Леонтьева Е. С., Егоров М. А., Кузнецова Р. Г. Иммуногистохимические маркеры в диагностике предраковых поражений слизистой оболочки полости рта и красной каймь губ. Практическая медицина. 2012; 1: 20-22.

12. Максимовская Л. Н, Эрк А. А., Булгакова Н. Н., Зубов Б. В.
Применение аутофлуоресцентной стоматоскопии для онкоскрининга заболеваний слизистой оболочки полости рта. Стоматология для всех. 2016; 4 (77): 34-37.

13. Пурсанова А. Е., Казарина Л. Н., Гущина О. О., Серхель Е. В., Белозеров А. Е., Абаев З. М. Клинико-иммунологические особенности предраковых заболеваний слизистой оболочки рта и красной каймы губ. Стоматология. 2018; 5: 23-26.

14. Позднякова Т. И, Смирнова Ю. А, Волков Е. А, Булгакова Н. Н. Возможности аутофрлуоресцентной спектроскопии в выявлении предраковых заболеваний слизистой оболочки полости рта. Дентал-Ревю. 2013; 2: 46-47.

15. Amirchaghmaghi M, Mohtasham N, Delavarian Z, Shakeri MT, Hatami M, Mozafari PM. The diagnostic value of the native fluorescence visualization device for early detection of premalignant/malignant lesions of the oral cavity. Photodiagnosis Photodyn Ther. 2018; 21: 19-27.

16. Simonato LE, Tomo S, Navarro RS, Villaverde AGJB. Fluorescence visualization improves the detection of oral, potentially malignant, disorders in population screening. Photodiagnosis Photodyn Ther. 2019; 27: 74-8.

17. Meleti M, Giovannacci I, Vescovi P, Pedrazzi G, Govoni P, Magnoni C. Histopathological determinants of autofluorescence patterns in oral carcinoma. Oral Dis. 2020.

18. Шухорова Ю. А., Ткач Т. М., Буракшаев С. А., Постников М. А. Онконастороженность в практике врача-стоматолога на амбулаторном приеме. Институт стоматологии. 2020; 3 (88): 20-22.

19. Орлов А. Е., Каганов О. И., Постников М. А., Воздвиженский М. О., Трунин Д. А., Махонин А.А., Габриелян А. Г, Ткачев М. В., Кирилова В. П., Осокин О. В., Керосиров А. П., Ахмадиева Е. О., Баранов Р. А., Шурыгина О. В., авторы. Способ определения показаний для выполнения гистологической верификации образования красной каймы губ и слизистой полости рта у больного на приеме у врача стоматолога. Патент РФ № 2019133760. 22.10.2019. 